"SOCIALIZATION \& HUMAN DEVELOPMENT" INTERNATIONAL JOURNAL

\title{
DYNAMICS OF DEVELOPMENT OF THE EDUCATORS' PROFESSIONAL SELF-CONSCIOUSNESS IN THE PROCESS OF PROFESSIONAL SKILLS IMPROVING
}

https://doi.org/10.37096/SHDISJ-20-1.1-0008

\author{
Sedykh Kira \\ https://orcid.org/0000-0003-3528-7569 \\ Metelska Nataliia \\ https://orcid.org/0000-0002-4034-9034
}

\begin{abstract}
The article is devoted to the study of the problem of dynamics of development of professional self-consciousness of educators in the process of professional skills improving. To the empirical research were involved 385 individuals - senior students who do not have professional experience; educators who at the time of the study worked on the specialty less than 5 years, from 5 to 10 years or more than 10 years.

It was found that the value-semantic component is the most important component in the self-consciousness of specialists of pedagogical profession, regardless of the level of qualification. The cognitive component gaines more weight for educators with 5 to 10 years of experience and more than 10 years of experience. The weight of the evaluative component decreases with the increase of professional experience. Emotional component acquires the greater value for pedagogues with more than 10 years of experience and the least value for educators with up to 5 years of experience. The regulatory component gaines more weight for employees with up to 5 years of experience and undergraduate students. Motivational component has the least importance for the undergraduate students. The volitional aspect of professional self-consciousness gaines the most weight for future educators.

Therefore, there are differences in the process of development of all components of educators' professional self-consciousness with different levels of qualification. Making sense of one's own professional activity and awareness of oneself as part of professional community is important, regardless of professional experience. With the increase of professional qualification, the role of professional self-esteem and selfacceptance in the activity decreases, but the level of self-understanding in the profession increases. With the increase of skills level, educators pay less attention to the issues of self-control and self-regulation in their professional activities.

Keywords: professional self-consciousness, structural components of professional self-consciousness, educators.

\section{Introduction}

The solution of the urgent tasks that are currently facing the educational system of Ukraine requires an exceptional attention to the professional training of her professional self-consciousness.
\end{abstract}


"SOCIALIZATION \& HUMAN DEVELOPMENT" INTERNATIONAL JOURNAL

The purpose of the research is to determine the dynamics of development of educators' professional self-consciousness in the process of professional skills improving.

\section{Theoretical background}

The problem of professional selfconsciousness development is not new in psychology. It was considered in the works of many researchers (B. Ananiev, M. Bakhtin, M. Kahan, O. Leontiev, etc.). General psychological and methodological aspects of professional self-consciousness are revealed in the works of K. Abulkhanova-Slavskaya,

R. Burns I. Kon, A. Petrovskyi, K. Rogers, V. Slobodchykov and others. According to their views self-consciousness should be seen as a separate phenomenon of human psychics which determines the selfregulation of person's own actions in the professional area on the basis of awareness of the profession requirements, one's abilities in the profession and emotional attitude to oneself as a subject of professional activity.

O. Bodrov, A. Derkach, Y. Kuliutkin, H. Metelskyi,

D. Nikolenko, S. Pashchenko, and others devoted their attention to the analysis of formation patterns of educators professional selfconsciousness. According to scientific research of the psychological structure of personality and activity of pedagogues, improvement of their professional training and development of pedagogical skills, conducted by I. Bekh, O. Vlasova, V. KanKalyk, V. Krutetskyi, A. Kuzminskyi, A. Markova, S. Maksymenko, L. Rymar and others, the main basis for the formation of the pedagogue's personality is his or her professional self-consciousness.

According to K. Sedykh (Sedykh, 2009: 211), in recent years there has been a shift in researchers' interest from the development and description of normative models of personality and activity of a specialist to the study of professional consciousness and self-consciousness of the subject of activity.

However, an analysis of the psychological literature showed that currently there is no single approach to interpreting the concept of "professional self-consciousness of the personality". Thus, L. Mitina (Mitina, 1998) defines professional self-consciousness as the awareness of oneself in each of three components of the working space, namely in the system of one's own professional activity, in the system of professional communication and in the system of one's personality.

A. Derkach (Derkach, 2004) views professional self-consciousness as an independent psychological and acmeological category; as an evolving system; as a personal entity specific to the subject of activity. Professional selfconsciousness is manifested in personal qualities that are refracted through professional knowledge and demonstrated in the situation of professional life.

Y. Katiuk (Katiuk, 2015) defines professional self-consciousness as a complex personal entity that develops under the influence of the professional environment and the active participation of the subject in professional activity, that is, the aware attitude of a person to his or her professional needs, motives, abilities and behavior.

O. Moskalenko (Moskalenko, 2000) created an acmeological concept of the professional self-consciousness development in the context of general personal and professional formation of a person, which is aimed at achieving the 
"SOCIALIZATION \& HUMAN DEVELOPMENT" INTERNATIONAL JOURNAL

"acme", or a higher degree of selfrealization. In her research the main role of professional self-consciousness in the development of such phenomena of personality professional development as professional motivation, value orientations, psychological readiness for professional activity, professional self-affirmation, selfexpression, career growth, professional creativity is proved.

According to the scientific research of L. Mitina (Mitina, 1998) and A. Markova (Markova, 1996), the structure of the professional self-consciousness of the personality is an interconnected combination of three substructures, which are cognitive, affective and behavioral ones.

A. Derkach, O. Moskalenko and their colleagues (Derkach, Moskalenko, Piatin, Selezneva, 2000) offered their own approach to considering the structure of professional self-consciousness. They distinguished the following functional components of professional selfconsciousness: cognitive, which is realized in self-knowledge; emotional, which is realized in self-understanding; motivational and targeted, which is realized in self-actualization; operational, which is realized in self-regulation.

\section{According to O. Priazhnykova} (Pryazhnikova, 2001), the structure of professional self-consciousness includes the idea about the sense of one's work, the specific goals and objectives of professional activity, its methods and organization, about one's own formal and real job status, about oneself as a member of the working collective, about the prospects of professional and personal development, as well as about one's own real and ideal professional qualities.

Speaking about the specifics of the pedagogue's

professional

selfconsciousness, it is possible to say that it is determined with the peculiarities of the profession itself, because the profession of teacher is marked with a quite considerable list of requirements for the morality of its representatives, responsibility for the results of their work, as well as with formation of pedagogical type of thinking and self-understanding in the profession in the process of activity on the specialty (Klimov, 2003).

In foreign studies, the issue of the pedagogue's professional selfconsciousness is usually included into the context of studying his or her professional identity. Thus, A. Karaolis and G. Philippou (Karaolis, Philippou, 2019) find it necessary to consider such concepts as self-efficacy, self-esteem, professional commitment, job satisfaction, task orientation, work motivation, and future perspective while exploring this phenomenon.

According to Belgian researcher G. Kelchtermans (Kelchtermans, 1993), the structure of pedagogue's professional self includes self-image, self-esteem, job motivation, task perception, and future perspective.

However, despite increased researchers' attention to this problem, some aspects of it have not been sufficiently studied yet. Thus, the analysis of the psychological and pedagogical literature showed that until now the specifics of the development of the components of the educators' professional self-consciousness and the dynamics of these components in the course of professional experience gaining are not experimentally studied.

\section{Methodology}

The program of empirical research of educators' professional self-consciousness 
"SOCIALIZATION \& HUMAN DEVELOPMENT" INTERNATIONAL JOURNAL

includes: "Test questionnaire of selfattitude" (by V. Stolin, S. Panteleyev); "Purpose in life test" (PIL, by J. Crumbaugh, L. Maholick, adaptation by D. Leontiev); "Methods of diagnosis of personality motivation to success" (by T. Ehlers); Test questionnaire "Need for goal achievement" (by Y. Orlov); methodics "Personal differential" (adapted at the V.N. Bekhterev Research Institute variant). The research was conducted on the basis of Poltava V.G. Korolenko National Pedagogical University and the M.V. Ostrogradsky Poltava Regional Institute of Postgraduate Pedagogical Education and covered 385 people. We have identified the following categories of studied subjects:

- group 1, which consists of senior students of pedagogical specialties who have no professional experience $\left(\mathrm{n}_{1}=110\right)$;

- group 2, composed of employees of educational institutions who at the time of the study had worked on a spesialty for less than 5 years $\left(\mathrm{n}_{2}=82\right)$;

- group 3, which included pedagogues who at the time of the study worked on the specialty from 5 to 10 years $\left(n_{3}=106\right)$;

- group 4, comprised of educators who at the time of the study have worked on the specialty for more than 10 years $\left(\mathrm{n}_{4}=87\right)$.

As we obtained a wide range of empirical data, the factor analysis with the Varimax rotation procedure with Kaiser normalization was applied to summarize and consolidate it. For the factor analysis we separated 23 variables that reflect the data of empirical research methodics. Factor analysis was conducted for each of the study groups individually in order to determine the most important peculiarities of the development of their professional self-consciousness. We used the IBM SPSS Statistics for Windows, Version 23.0 statistical software package for the detailed calculations (Pallant, 2011).

\section{Results}

At first we make a comparative analysis of the specifics of the professional self-consciousness of educators with different levels of qualification in order to identify those peculiarities of the phenomenon that are different for persons with different degrees of professional experience. We analyze the data of the first group of studied subjects - senior students of pedagogical specialties $\left(\mathrm{n}_{1}=110\right)$. According to the results of factor analysis (measure of sampling adequacy of KaiserMeyer-Olkin $=0.781), 7$ factors were extracted that explain $73.64 \%$ of total variance.

The first factor F1 (factor weight is 8.271) includes such components as "General meaningfullness of life index" (0.894), "Life efficiency, or satisfaction with self-realization" (0.815), "Life locus of control" (0.801), "Life purposes" (0.797), "Self locus of control" (0.764) and "Motivation for success" (0.407). The content of this factor reflects the degree of understanding of one's own life by undergraduate students, the vision of meaning in their life and professional way, and the ability to manage their professional activity. The factor also shows the degree of purposefulness, the ability to build life and a professional career in accordance with their goals and perceptions of their meaning, the tendency to focus on their own strengths, achieve their goal in professional activity. Summarizing the meaning of the factor, it can be considered as describing the value-semantic component of professional selfconsciousness.

The second factor F2 (factor weight is 2.239) includes such components as 
"SOCIALIZATION \& HUMAN DEVELOPMENT" INTERNATIONAL JOURNAL

"Expected attitude from others" (0.798), "Attitudes from others" (0.765), and "Selfinterest (as an attitude to one or another internal actions towards one's self)" (0.664), "Self-interest" (0.635), "Global self-attitude" (0.525), and "Selfconfidence" (0.494). This factor reflects the expectations of undergraduate students for a certain attitude from others, their tendency to self-change, the attempt to come closer to a perfect idea about the specialist, the presence of interest to their own thoughts and feelings, general selfatittude and the level of self-esteem in the professional area. So the characteristics of this factor make it possible to consider it as describing the evaluative component of professional self-consciousness.

The third factor F3 (factor weight is 1.735) includes such components as "Global self-attitude" (0.495), "Selfunderstanding" (0.790), "Self-respect" (0.787), "Self-confidence" (0.546), and "Self-management, self-consistency" (0.514). The semantics of this factor include the general self-attitude of senior students, awareness of themselves as future professionals, the degree of selfunderstanding, the ability to control their own lives and activities. Summarizing the characteristics of this factor, it can be considered as describing the cognitive component of professional selfconsciousness.

The fourth factor F4 (factor weight is 1.393) includes components such as "Global self-attitude"

(0.412), "Autosympathy" (0.843) and "Selfacceptance" (0.660). At the same time, the components "Self-blame" (-0.833) and "Motivation for success" (-0.425) were included with the negative indicator. The semantics of this factor reflect the general self-attitude of undergraduates, their self- acceptance in general, trust to themselves and positive self-esteem, acceptance of themselves as persons and specialists, lack of inclination to express unjustified accusations about themselves and tendency to avoid failure more than strive to achieve. Taking into consideration the characteristics of this factor, it can be considered as describing the emotional component of professional selfconsciousness.

Fifth factor F5 (factor weight is 1.187) includes components such as "Activity" (0.825), "Evaluation" (0.662) and "Strength" (0.565). The content of this factor reflects the activity, sociability and possible impulsivity in the area of professional activity, the degree of acceptance of oneself and one's own level of achievements in professional activity, the development of volitional aspects of the personality. Considering the characteristics of this factor, it can be considered as describing the regulatory component of professional self-consciousness.

The sixth factor F6 (factor weight is 1.070) includes components such as "The process of life, or interest and emotional saturation of life" (0.674) and the opposite relation to "Self-management, selfconsistency" (-0.609). This factor reflects students' perceptions of professional life as interesting, emotionally rich, and filled with meaning, as well as their ability to control their own lives and activities. Summarizing the content of this factor, it can be considered as describing the volitional component of professional selfconsciousness.

The seventh factor F7 (factor weight is 1.042) includes the component "Achievement motivation" (0.913). The semantics of this factor include the tendency to get involved into work, the will 
"SOCIALIZATION \& HUMAN DEVELOPMENT" INTERNATIONAL JOURNAL

to do things better than before, and the need to invent new ways of doing ordinary tasks. Therefore, the characteristics of this factor make it possible to consider it as describing the motivational component of professional self-consciousness.

Next, we analyze the data of the second group of respondents, employees of educational institutions who at the time of the study worked on the specialty for less than 5 years $\left(\mathrm{n}_{2}=82\right)$. According to the results of factor analysis (measure of sampling adequacy of Kaiser-Meyer-Olkin $=0.748), 6$ factors were extracted that explain $70.11 \%$ of total variance.

The first factor F1 (factor weight is 7.557) includes such components as the "General meaningfullness of life index" (0.943), "Life locus of control" (0.878), "The process of life, or interest and emotional saturation of life" (0.814), "Life efficiency, or satisfaction with selfrealization" (0.806), "Life purposes" (0.789), "Self locus of control" (0.712), "Global self-attitude" (0.558), "Selfrespect" (0.545), and "Self-confidence" ( $0.427)$. The semantics of this factor reflect the degree of understanding of one's life by educators with little work experience, their ability to make decisions and implement them freely, as well as a sense of the segment of life as a productive and meaningful part of their professional way, the existence of purposes in the future, which give the meaningfulness, focus and time perspective to life. Substantive meaning of this factor includes sufficient freedom of choice to build one's life and professional career in accordance with one's goals and ideas about their meaning, the general self-attitude of pedagogues and their level of self-esteem, trust to their abilities, understanding of their own role in professional success achieving.
Summarizing the characteristics of this factor, it can be considered as describing the value-semantic component of professional self- consciousness.

The second factor F2 (factor weight is 2,594 ) includes such components as "Selfinterest" (0.784), "Self-interest (as an attitude to one or another internal actions towards one's self)" (0.780), "Expected attitude from others" ( 0.729) and "Attitudes from others" (0.667). The content of this factor reflects a tendency to self-change in order to get closer to the ideal idea of oneself, the interest to one's own thoughts and feelings as a specialist, the idea of how educators are able to arouse respect, sympathy, approval or understanding from others. Taking into consideration the characteristics of this factor, it can be considered as describing the evaluative component of professional self-consciousness.

The third factor F3 (factor weight is $1.865)$ includes such components as "Selfunderstanding"

"Selfmanagement, self-consistency" (0.721) and "Self-respect" (0.561). This factor reflects the employees' awareness of themselves as specialists, their ability to control their own lives and activities, and their level of understanding of their professional capacities. Taking into consideration the characteristics of this factor, it can be considered as describing the cognitive component of professional selfconsciousness.

The fourth factor F4 (factor weight is 1.584) includes such components as "Activity" (0.731), "Motivation for success" (0.676), "Strength" (0.609) and "Evaluation" (0.544). The semantics of this factor include activity, sociability in professional behavior, attitude to oneself and one's own level of achievement, in 
"SOCIALIZATION \& HUMAN DEVELOPMENT" INTERNATIONAL JOURNAL

particular in professional activity, development of volitional aspects of the personality, tendency to focus on one's own strengths, achieve the set purpose in professional activity. Summarizing the characteristics of this factor, it can be considered as describing the regulatory component of professional selfconsciousness.

The fifth factor F5 (factor weight is $1.321)$ includes components such as "Selfacceptance" (0.795), "Self-confidence" (0.485), and "Autosympathy" (0.594). The semantics of this factor reflect a sense of sympathy for oneself, the acceptance of educators by themselves as they are, the attitude to themselves as volitional and reliable ones, a sense of themselves as regulators of achievement and professional success, the approval of themselves in general, trust to themselves and self-esteem of educators. Thus, the substantive capacity of this factor makes it possible to consider it as describing the emotional component of professional self-consciousness.

The sixth factor F6 (factor weight is 1.204) includes the component "Autosympathy" (0.636). At the same time, the components "Self-blame" (-0.813) and "Achievement motivation" (-0.545) were included with the negative indicator. The content of this factor reflects the pedagogues' trust to themselves, the lack of a tendency to express unjustified accusations about themselves, satisfaction with the achieved and lack of will to enjoy the pleasure of life and professional achievements in any case. Summarizing the characteristics of this factor, it can be considered as describing the motivational component of professional selfconsciousness.

Let us analyze the data of the third group of respondents - employees of educational institutions who at the time of the study worked on the specialty from 5 to 10 years $\left(n_{3}=106\right)$. According to the results of factor analysis (measure of sampling adequacy of Kaiser-Meyer-Olkin $=0.746), 6$ factors were extracted that explain $71.73 \%$ of total variance.

The first factor F1 (factor weight is 7,928 ) includes such components as the "General meaningfullness of life index" (0.954), "Life locus of control" (0.864), "Self locus of control" (0.801), "Life purposes" (0.781), "Life efficiency, or satisfaction with self-realization" (0.759), "The process of life, or interest and emotional saturation of life" (0.747), "Selfconfidence" (0.478), "Global self-attitude" (0.478), "Self-understanding" (0.402) and "Self-respect" (0.465). This factor reflects the degree of meaningfulness of one's life, orientation to one's semantic directions, conviction in one's ability to control his or her own life in order to build a professional career in accordance with one's goals and ideas about their meaning, a sense of one's professional career as a meaningful, interesting, emotional rich and contented part of life, general self-attitude of educators, awareness of the value of themselves as specialists, trust to their own strength. Considering the characteristics of this factor, it can be seen as describing the value-semantic component of professional self-consciousness.

The second factor F2 (factor weight is 2,553) includes such components as "Global self-attitude" (0.437), "Autosympathy" (0.911), and "Selfacceptance" (0.643). At the same time, components "Self-blame" (-0.801) and "Achievement motivation" (-0.504) were included into this factor with negative index. The semantics of this factor include the general self-attitude of educators, 
"SOCIALIZATION \& HUMAN DEVELOPMENT" INTERNATIONAL JOURNAL

understanding and acceptance of themselves as they are, lack of inclination to make unjustified accusations about themselves, enjoyment of easy success and simple tasks in professional activity. Considering the characteristics of this factor, it can be seen as describing the cognitive component of professional selfconsciousness.

The third factor F3 (a factor weight of 2,096), includes components such as "Attitudes from others" (0.871), "Expected attitudes from others" (0.859), and "Selfmanagement, self-consistency" (0.432). The semantics of this factor reflect an idea of the extent to which their personality is capable of arousing the respect, sympathy, approval or understanding of others, the ability to control their own lives and activities. Summarizing the characteristics of this factor, it can be considered as describing the evaluative component of professional self-consciousness.

The fourth factor F4 (factor weight is 1.572) includes components such as "Global self-attitude" (0.453), "Selfinterest" (0.837) and "Self-interest (as an attitude to one or another internal actions towards one's self)" (0.822). The content of this factor reflects an internally undifferentiated sense of "for" or "against" oneself, an attempt to come closer to a perfect idea of oneself, an interest to one's own thoughts and feelings, a willingness to communicate with oneself on an equal basis with both one's personality and professional self. Thus, the meaning of this factor make it possible to consider it as describing the emotional component of professional self-consciousness.

The fifth factor F5 (factor weight is 1.224) includes such components as "Evaluation" (0.783), "Motivation for success" (0.629), "Self-respect" (0.517) and "Self-management, self-consistency" (0.500). This factor reflects the degree of acceptance of oneself as a person and the level of satisfaction with oneself, the presence of a critical attitude towards oneself and one's own level of achievements in professional activity, the tendency to focus on one's own strengths, to achieve one's goal in professional activity, the ability to control one's own activity and to be self-consistent in achieving the results. Summarizing the characteristics of this factor, it can be considered as describing the motivational component of professional selfconsciousness.

The sixth factor F6 (factor weight is 1.124) includes components such as "Activity" (0.849) and "Strength" (0.552). The semantics of this factor include the activity, sociability and possible impulsivity in the area of professional activity, the development of the volitional aspects of the personality, which affects their professional functioning. Considering the characteristics of this factor, it can be seen as describing the regulatory component of professional selfconsciousness.

Let us analyze the data of the fourth group of respondents - employees of educational institutions, who at the time of the study worked on the specialty for over 10 years $\left(\mathrm{n}_{4}=87\right)$. According to the results of factor analysis (measure of sampling adequacy of Kaiser-Meyer-Olkin $=0.776$ ), 6 factors were extracted, which explain $71.72 \%$ of total variance.

The first factor, F1 (factor weight is 8,699), includes such components as the "General meaningfullness of life index" (0.891), "The process of life, or interest and emotional saturation of life" (0.784), "Life locus of control" (0.765), "Life efficiency, 
or satisfaction with self-realization" (0.732), "Self locus of control" (0.682), "Life purposes" (0.656), "Achievement motivation" (0.632), "Strength" (0.419), and "Self-respect" (0.454). The semantics of this factor reflect the degree of understanding of one's life by the studied subjects, the conviction of being able to control one's life, to make decisions and implement them freely, as well as to manage one's professional activity, the feeling of the passed segment of life as a productive and meaningful part of one's life and professional way, persistence in achievement of one's goals in professional activity, presence of goals in the future, development of volitional aspects of the personality, self-understanding, independence. Considering the meaning of this factor, it can be seen as describing the value-semantic component of professional self-consciousness.

The second factor F2 (factor weight is 2,425) includes such components as "Autosympathy" (0.842), "Global selfattitude" (0.626), "Self-understanding" (0.575), "Self-respect" (0.547) and "Selfacceptance" (0.643). The component "Selfblame" (-0.869) was included into this factor with negative index. The content of this factor reflects sociability or hostility to one's self, internally undifferentiated sense of "for" or "against" oneself, value of their personality for educators, awareness of themselves as specialists, evaluation of their capabilities, ability to control their life, acceptance of themselves as they are, understanding of themselves as persons and specialists, lack of inclination to consider themselves as the cause of troubles that occur in the professional environment. Summarizing the characteristics of this factor, it can be considered as describing the cognitive component of professional self-consciousness.

The third factor F3 (factor weight is 1.517) includes such components as "Global self-attitude" (0.414), "Selfacceptance" (0.410), "Self-interest" (0.893), and "Self-interest (as an attitude to one or another internal actions towards one's self)" (0.816). This factor reflects an internally undifferentiated sense of "for" or "against" oneself, the general self-attitude of pedagogues and their level of selfesteem, which extends to the professional area, the tendency to self-change, the degree of closeness to themselves, feelings of sympathy to themselves, acceptance of themselves as they are, harmony with their internal intentions. Therefore, the characteristics of this factor make it possible to consider it as describing the emotional component of professional selfconsciousness.

The fourth factor F4 (factor weight is 1.439) includes such components as "Activity" (0.765), "Self-confidence" (0.656) and "Motivation for success" (0.646). The semantics of this factor include activity, sociability and possible impulsivity in professional activity, the idea of the main source of one's own activity, results and achievements, the tendency to focus on one's own strengths, to achieve one's goal in life and one's professional activity. Summarizing the characteristics of this factor, it can be considered as describing the motivational component of professional selfconsciousness.

The fifth factor F5 (factor weight is 1.250) includes components such as "Attitude from others" (0.910) and "Expected attitude from others" (0.764). The semantics of this factor reflects the perceptions of educators about the extent to which they are able to arouse respect, 
"SOCIALIZATION \& HUMAN DEVELOPMENT" INTERNATIONAL JOURNAL

sympathy, approval or understanding from others. Summarizing the characteristics of this factor, it can be considered as describing the evaluative component of professional self-consciousness.

The sixth factor F6 (the factor weight is 1.164) includes such components as "Self-management, self-consistency" (0.766) and "Evaluation" (0.727). The content of this factor reflects the ability of educators to control their lives and activities carefully, accepting themselves as personalities and satisfaction with themselves, critical attitude to themselves and their own level of achievement in professional activity. Taking into account the meaning of this factor, it can be considered as describing the regulatory component of professional self- consciousness.

Generalized factor analysis data for the entire sample of subjects are presented in Table. 1.

Analyzing the data in the table, we can conclude that the value-semantic component is the main in the structure of professional self-consciousness of educators at all stages of professional experience gaining (average rank $=1$ ), that is, the ability of the professional to understand the surrounding reality, establish personal sense of activity and ideas connected with the profession, is the most important component in the selfconsciousness of pedagogical professionals, regardless of the level of qualification.

Table 1. The hierarchy of empirically selected factors in the structure of professional self-consciousness of educators

\begin{tabular}{|l|c|c|c|c|c|}
\hline \multirow{2}{*}{$\begin{array}{c}\text { Components of } \\
\text { professional self- } \\
\text { consciousness }\end{array}$} & \multicolumn{4}{|c|}{ Ranks for research groups } & Average rank \\
\cline { 2 - 5 } for a component \\
Value-semantic & 1 & 1 & 1 & 1 & 1 \\
\hline Evaluative & 2 & 2 & 3 & 5 & 3 \\
\hline Cognitive & 3 & 3 & 2 & 2 & 2,5 \\
\hline Emotional & 4 & 5 & 4 & 3 & 4 \\
\hline Regulatory & 5 & 4 & 6 & 6 & 5,25 \\
\hline Volitional & 6 & - & - & - & 6 \\
\hline Motivational & 7 & 6 & 5 & 4 & 5,5 \\
\hline
\end{tabular}

Cognitive component of professional self-consciousness of educators can be considered as one of the leading ones (average rank $=2.5$ ), that is awareness of oneself as a person and a specialist, understanding of the characteristics of one's profession, professional community, the ideal of the pedagogue, as well as one's professionally important qualities. This component gaines more weight with the development of professional qualification, namely, for educators with 5 to 10 years of experience and more than 10 years of working experience.

Educators with up to 5 years of experience and undergraduate students are more likely to give more weight to the evaluative component than to cognitive component of professional selfconsciousness (average rank $=3$ ), which is seen by us as an integral part of the emotional-evaluative component and is expressed in self-esteem and selfacceptance of oneself as a specialist. The 
"SOCIALIZATION \& HUMAN DEVELOPMENT" INTERNATIONAL JOURNAL

weight of this component decreases with the growth of professional experience.

The next in the hierarchy of components is the emotional component (average rank $=4$ ), which we understood as an integral part of the emotional-evaluative component, as the previous one. It is expressed in the attitude of educators to themselves as professionals, which is manifested in self-esteem, self-respect, self-interest, sympathy for oneself as a representative of the teaching profession. The emotional component becomes more important for educators with more than 10 years of experience, and the least important for educators with up to 5 years of experience.

The regulatory component, which is the next in the hierarchical structure of professional self-consciousness of educators (average rank $=5.25$ ), manifests itself in self-regulation while pedagogical tasks solving, in potential behavioral reactions in situations of professional activity, in goals setting and achieving. This component gaines more weight for workers with up to 5 years of experience and undergraduate students, and as their professional skills grow, its weight decreases.

The next is the motivational component of the professional selfconsciousness of educators (average rank $=$ 5.5), which consists of professional motivation, motives for professional improvement that provide the need for selfactualization, and the will to succeed in professional activity. Motivational component has the least weight for the undergraduate students, but it gradually increases with the pedagogues' professional skills improving.

Another component identified during the analysis was volitional, which was extracted only for senior students (average rank $=6$ ). We understand this component as an integral part of the regulatory one, which finds expression in the development of volitional qualities, the ability to control one's own life and activities with their help. In this regard, we can say that the volitional aspect of professional self-consciousness gaines the biggest weight for future educators.

\section{Discussion}

Thus, the value-semantic component, that is, the professional's ability to comprehend the surrounding reality, establish personal meaning of activities and ideas related to the profession, is the most important component in the self-consciousness of professionals of the teaching profession, regardless of the level of qualification. The cognitive component gaines more weight with the growth of professional skills, namely, for educators with 5 to 10 years of experience and more than 10 years of working experience. The weight of the evaluation component decreases with the increase of professional experience. Emotional component acquires the biggest value for pedagogues with more than 10 years of experience and the least value for educators with up to 5 years of experience. The regulatory component gaines more weight for workers with up to 5 years of experience and undergraduate students, and as their professional skills grow, its weight decreases. The undergraduate students have the least value of motivational component, but it increases gradually with the professional development of teachers. The volitional aspect of professional self-consciousness gaines the biggest weight for future educators. 
The results of our study are to a certain extent confirmed by the data of scientific research of E. Maksimović and E. Osmanović (Maksimović, Osmanović, 2019), who came to the conclusion that work experience influences the peculiarities of teachers' self-concept development. Thus, scientists proved the dependence of acceptance of teachers' own selves, self-improvement, satisfaction with their own selves, their achievements and their own profession as a whole on the level of qualification.

\section{Conclusion}

Thus, the results of the comparative study showed that there are differences in the level of development of all components of educators' professional selfconsciousness with different levels of qualification. Making sense of one's professional activity and awareness of oneself as a part of a professional community is important, regardless of professional experience. With the increase of professional qualification, the role of professional self-esteem and selfacceptance in activity decreases, but the level of self-understanding in the profession increases. With the increase of skills level, educators pay less attention to the issues of self-control and selfregulation in their professional activities. This is confirmed by the fact that volitional qualities in the structure of professional self-consciousness are allocated for themselves only by students without professional experience. Also, as the level of qualification increases, the motivation for professional activity becomes more important, that is, pedagogues are more able to pay attention to the need for selfactualization.

The conducted research does not exhaust all aspects of the problem under study. Prospects for further exploration are to study the structure of professional selfconsciousness of educators, depending on their specialization.

Conflict of interest. We state that there is no conflict of scientific interests.

\section{References}

Derkach, A. A. (2004). Akmeologicheskie osnovy razvitiya professionala [Acmeological bases of the professional development]. Moscow: Izdatelstvo Moskovskogo psihologo-sotsialnogo instituta [in Russian].

Derkach, A. A., Moskalenko, O. V., Pyatin, V.A. \& Selezneva, E. V. (2000). Akmeologicheskie osnovy professionalnogo samosoznaniya lichnosti [Acmeological bases of professional self-consciousness of personality]. Astrahan: Izdatelstvo Astrahanskogo gosudarstvennogo pedagogicheskogo universiteta [in Russian].

Karaolis, A., Philippou, G.N. (2019). Teachers' Professional Identity. In: Hannula, M., Leder, G., Morselli, F., Vollstedt, M., Zhang, Q. (eds) Affect and Mathematics Education. ICME13 Monographs. Springer, Cham.

Katiuk, Y. L. (2015). Osobystisnooriientovani zasady rozvytku profesiinoi samosvidomosti maibutnikh psykholohiv u systemi pisliadyplomnoi pedahohichnoi osvity [Personally oriented principles of development of professional self-consciousness of future psychologists in the system of postgraduate pedagogical education]. In Osobystisnooriientovana pidhotovka maibutnikh psykholohiv u systemi 
"SOCIALIZATION \& HUMAN DEVELOPMENT" INTERNATIONAL JOURNAL

pisliadyplomnoi pedahohichnoi osvity [Personally-oriented training of future psychologists in the system of postgraduate pedagogical education]. Kyiv: NAPN of Ukraine, Universytet menedzhmentu osvity, 127-152 [in Ukrainian].

Kelchtermans, G. (1993) Getting the story, understanding the lives: from career stories to teachers' professional development. Teaching and Teacher Education, 9 (5 / 6), 443-456.

Klimov, E. A. (2003). Psihologiya professionala: izbrannye psihologicheskie trudy [Professional psychology: selected psychological works]. Moscow: Izdatelstvo Moskovskogo psihosotsialnogo instituta; Voronezh: Izdatelstvo NPO "MODEK" [in Russian].

Maksimović, J. \& Osmanović, J. (2019). Teachers' self-concept and its benefits for science education. Journal of Baltic Science Education, vol. 18, 1. 105-116.

Markova, A. K. (1996). Psihologiya professionalizma [Psychology of professionalism]. Moscow: Mezhdunarodnyiy gumanitarnyiy fond "Znanie" [in Russian].

Mitina, L. M. (1998). Psihologiya professionalnogo razvitiya uchitelya [Psychology of teacher professional development]. Moscow: Flinta [in Russian].
Moskalenko, O. V. (2000). Razvitie professionalnogo samosoznaniya rukovoditeley obrazovatelnyh uchrezhdeniy [Development of professional self-consciousness of the heads of educational institutions] (Extended abstract of $\mathrm{PhD}$ dissertation). Moscow: Russian Presidential Academy of Public Administration [in Russian].

Pallant, J. (2011). SPSS survival manual: A step by step guide to data analysis using the SPSS program. 4th Edition, Allen \& Unwin, Berkshire.

Pryazhnikova, E. Y. (2001). Psihologicheskie osnovy razvitiya professionalnogo samosoznaniya profkonsultanta [Psychological bases of the development of professional self-consciousness of a professional consultant] (Extended abstract of Doctoral dissertation). Tver: Tver State University [in Russian].

Sedykh, K. V. (2009). Supervizii dlia shkilnykh psykholohiv-konsultantiv [Supervisions for school counseling psychologists]. In Aktualni problemy psykholohii [Actual problems of psychology]. Kyiv: Instytut psykholohii imeni H.S. Kostiuka NAPNU, vol. 7, 19, 211215 [in Ukrainian]. 